\title{
Land cover changes and greenhouse gas emissions in two different soil covers in the Brazilian Caatinga
}

\author{
Kelly Ribeiro ${ }^{\mathrm{a}, \mathrm{b}}$, Eráclito Rodrigues de Sousa-Neto ${ }^{\mathrm{a}, *}$, João Andrade de Carvalho Junior ${ }^{\mathrm{b}}$, \\ José Romualdo de Sousa Lima ${ }^{c}$, Rômulo Simões Cezar Menezes ${ }^{\mathrm{d}}$, Paulo José Duarte-Neto ${ }^{\mathrm{e}}$, \\ Glauce da Silva Guerra ${ }^{\mathrm{e}}$, Jean Pierre Henry Baulbaud Ometto ${ }^{\text {a }}$ \\ ${ }^{a}$ Centro de Ciência do Sistema Terrestre - CCST, Instituto Nacional de Pesquisas Espaciais - INPE, São José dos Campos, SP, Brazil \\ b Programa de Pós-Graduação em Engenharia Civil e Ambiental, Universidade Estadual de São Paulo - UNESP, Campus Guaratinguetá- SP, Brazil \\ c Unidade Acadêmica de Garanhuns, Universidade Federal Rural de Pernambuco - UFRPE, Garanhuns, PE, Brazil \\ ${ }^{\mathrm{d}}$ Universidade Federal de Pernambuco - UFPE \\ e Programa de Pós-Graduação em Biometria e Estatística Aplicada, Universidade Federal Rural de Pernambuco-UFRPE, Recife, PE, Brazil
}

\section{H I G H L I G H T S}

- Land use/cover changes have altered biogeochemical cycles in the Caatinga.

- Nitrous oxide and carbon dioxide emissions were significantly higher than methane.

- Gaseous emissions correlated with soil temperature and moisture

- There was no difference between emissions measured in native vegetation and pasture treatments.

\section{G R A P H I C A L A B S T R A C T}



\section{A B S T R A C T}

The Caatinga biome covers an area of $844,453 \mathrm{~km}^{2}$ and has enormous endemic biodiversity, with unique characteristics that make it an exclusive Brazilian biome. It falls within the earth's tropical zone and is one of the several important ecoregions of Brazil. This biome undergoes natural lengthy periods of drought that cause losses in crop and livestock productivity, having a severe impact on the population. Due to the vulnerability of this ecosystem to climate change, livestock has emerged as the main livelihood of the rural population, being the precursor of the replacement of native vegetation by grazing areas. This study aimed to measure GHG emissions from two different soil covers: native forest (Caatinga) and pasture in the municipality of São João, Pernambuco State, in the years 2013 and 2014. GHG measurements were taken by using static chamber techniques in both soil covers. According to a previous search, so far, this is the first study measuring GHG emissions using the static chamber in the Caatinga biome. $\mathrm{N}_{2} \mathrm{O}$ emissions ranged from -1.0 to $4.2 \mathrm{mg} \mathrm{m}^{-2} \mathrm{~d}^{-1}$ and -1.22 to $3.4 \mathrm{mg} \mathrm{m}^{-2} \mathrm{~d}^{-1}$ in the pasture and Caatinga, respectively, and they did not significantly differ from each other. Emissions were significantly higher during dry seasons. Carbon dioxide ranged from -1.1 to 14.1 and 1.2 to $15.8 \mathrm{~g} \mathrm{~m}^{-2} \mathrm{~d}^{-1}$ in the pasture and Caatinga, respectively. $\mathrm{CO}_{2}$ emissions were higher in the Caatinga in 2013, and they were significantly influenced by soil temperature, showing an inverse relation. Methane emission ranged from 6.6 to 6.8 and -6.0 to $4.8 \mathrm{mg} \mathrm{m}^{-2} \mathrm{~d}^{-1}$ in the pasture and Caatinga, respectively, and was significantly higher only in the

\footnotetext{
* Corresponding author.

E-mail address: eraklito@gmail.com (E.R. Sousa-Neto).
} 
Caatinga in the rainy season of 2014. Soil gas fluxes seemed to be influenced by climatic and edaphic conditions as well as by soil cover in the Caatinga biome.

\section{Introduction}

The Caatinga is a biome covered by semiarid vegetation with unique characteristics that make it an exclusive Brazilian biome (Gariglio et al., 2010; IBGE, 2004; Santos et al., 2011b). It covers an area of about
$844,453 \mathrm{~km}^{2}$ of the interior of the Northeast region, which is $11 \%$ of the Brazilian territory (Gariglio et al., 2010). The Caatinga has enormous endemic biodiversity, and around $50 \%$ of its original vegetation cover remains relatively intact despite the high human population density and high deforestation rates (Gariglio et al., 2010). The Caatinga falls entirely



Fig. 1. Map of northeastern Brazil and the Caatinga biome. Adapted from Menezes et al. (2012). 
within the earth's tropical zone and is one of six major ecoregions (biomes) of Brazil, including the Amazon Basin, Pantanal, Cerrado, Atlantic Forest, and Pampas (Gariglio et al., 2010).

According to Pereira Filho and Bakke (2010), there are four major edaphic-climatic zones in the Brazilian Northeast (Fig. 1) characterized by Zona da Mata (comprising the coastal region of the Northeast with regular rainfall and good soil fertility), Agreste (eastern transition to the Atlantic forests used to be a narrow stretch of deciduous forests), Sertão (known as a "drought polygon" system with very low and irregular rainfall, marked by an intense dry season), and Meio Norte (transition zone between the Amazon and the Northeast, with high rainfall influenced by the movement of the Atlantic equatorial mass (MEA) from the Amazon). The Caatinga biome is located only in the Agreste and Sertão zones.

One of the most striking features of the region is the severe drought periods that affect plant growth and have substantial social and economic impact on the population. The rains in the Caatinga region are usually concentrated in three to four months of the rainy season, causing a negative water balance and high aridity index (Giulietti et al., 2004) which has indirectly resulted in abandoning family farming and substitution by other activities such as extensive livestock and the migration of rural people to the large urban areas of Brazil (Barbieri, 2011; Sampaio, 2003).

Due to the agricultural vulnerability to climate change, livestock has emerged as the main activity of the rural population, being the precursor of systematic replacement of native vegetation by grazing areas and responsible for serious environmental problems such as loss of biodiversity and desertification (de Freitas et al., 2007; Leal et al., 2005; MMA, 1998; Oliveira et al., 2012; Pereira, 2000; Sousa et al., 2012). The area of pasture in the biome extends over $293,756.4 \mathrm{~km}^{2}$, representing 35.5\% of the biome and 19.8\% of the pasture area in Brazil (Bustamante et al., 2012), which is a significant area, as Brazil is one of the major cattle producers in the world. The expansion of the pasture area results in part from the growing demand for food, which has favored land cover change and land use changes (LUCC) and the resultant increase in rates of deforestation (Menezes et al., 2012). Beuchle et al. (2015) showed by using Landsat images an overall net loss of tree cover in Caatinga biome of 15,571 $\mathrm{km}^{2}$ over two decades (1990-2010) and concluded that the Caatinga biome has been under increasing anthropic pressure for many years. Most areas were predominantly converted into pastures and croplands and as a consequence of this scenario, these areas may become more susceptible to desertification processes (Sousa et al., 2012). Despite these severe changes, there is little information on how it affects GHG emissions.

Changes in land cover can influence the dynamics of the carbon and nitrogen cycles, changing patterns of soil GHG fluxes (Bortolon et al., 2009; Cerri et al., 2008; Fleischer et al., 2016; Menezes et al., 2012; Sousa et al., 2012), which makes the system a GHG source due to the lack of native vegetation (Watanabe and Ortega, 2011). Livestock is considered one of the major sources of greenhouse gas emissions (GHG) to the atmosphere, mainly carbon dioxide $\left(\mathrm{CO}_{2}\right)$, methane $\left(\mathrm{CH}_{4}\right)$ and nitrous oxide $\left(\mathrm{N}_{2} \mathrm{O}\right)$, which results from enteric fermentation, manure management, feed production, as well as indirectly from change in land use (Hristov et al., 2013; Smith et al., 2014; United States Department of Agriculture - USDA, 2008).

Among other functions, the native vegetation is an important regulator of the climate, biodiversity, biogeochemical cycles and the physical, chemical and biological properties of soil. Furthermore, native vegetation acts as a sink of GHG (Chapuis-Lardy et al., 2007; Henry et al., 2002; Kirschbaum, 2003). A considerable gain of woody vegetation has been reported by some studies (Beuchle et al., 2015; Redo et al., 2013) and the increase in vegetation could lead to a net carbon uptake from the atmosphere.

Conversion of native forest to pasture and agricultural land affects turnover of soil carbon and nitrogen and increases emissions of GHG in the short-term (Matson and Vitousek, 1990) However, little is known about soil $\mathrm{C}$ and $\mathrm{N}$ dynamics in semiarid regions, particularly in NE Brazil (Menezes et al., 2012; Ponce-Mendoza et al., 2010; Sousa et al., 2012; Zhao et al., 2009). Nevertheless, in the Caatinga biome, where a semiarid climate is predominant, the available studies are consistent in showing $\mathrm{N}$ and $\mathrm{P}$ as the most limiting nutrients in the soil (Menezes et al., 2012).

Furthermore, despite an extensive body of knowledge about the impact of LUCC on the environment, very little is known about such processes in the Caatinga biome (Katharina et al., 2016; Sampaio and Freitas, 2008; Sampaio and Costa, 2012). Caatinga is considered as one of the more neglected of Brazilian Biomes (Beuchle et al., 2015; Santos et al., 2011a) and data availability is limited to a few papers, theses or technical notes published in regional journals. A search of the main scientific journals yielded no study using a static chamber technique or other technique for GHG measurements in the Caatinga biome.

Thus, this study aimed to measure and compare $\mathrm{CO}_{2}, \mathrm{CH}_{4}$, and $\mathrm{N}_{2} \mathrm{O}$ soil emissions from a natural forest (Caatinga) and a pasture in order to assess the impact of changes in land use and soil gas emissions to atmosphere on a local and regional scale, and to evaluate the impact of these processes on this vast and poorly known semiarid ecosystem.

\section{Material and methods}

\subsection{Study site}

This study was conducted on a farm named Riacho do Papagaio, in São João municipality ( $8^{\circ} 48^{\prime} 35^{\prime \prime}$ S, 36 $24^{\prime} 20^{\prime \prime} \mathrm{W}, 690 \mathrm{~m}$ a.s.l.) in the State of Pernambuco, Brazil. At Riacho do Papagaio farm, the pasture was established in 1950 when the native Caatinga forest was cut down and replaced by Guatemala grass (Tripsacum laxum Nash), a perennial forage plant of this family of grasses (personal communication by the farm owner). The grass was replaced by beans (Phaseolus ssp) and manioc (Manihote sculenta) from 1975 to 1980. From 1981 to 1999, the soil was cultivated with corn (Zea mays) for silage; from 2000 up until now, the area was converted to pasture again, cultivated with another grass species (Brachiaria ssp).

According to the Brazilian Institute of Meteorology (INMET), this study area is characterized by warm and dry climate with historical average rainfall (1999-2011) of approximately $782 \mathrm{~mm}$ (APAC, 2015) (Fig. 2). As in other semiarid regions, the seasonal variability of rainfall is high, resulting in rainfall outside of the characteristic periods, with rainfall occurring mostly during months from May to August (Fig. 2). Temperatures are high and quite spatially and temporally uniform, with an annual average between $25{ }^{\circ} \mathrm{C}$ and $30{ }^{\circ} \mathrm{C}$ (Sampaio, 2003). The soil is classified as Entisol typical Eutrophic with predominantly sandy texture and considered an acidic soil ( $\mathrm{pH} \sim 5.4$ ) (Santos et al., 2012).

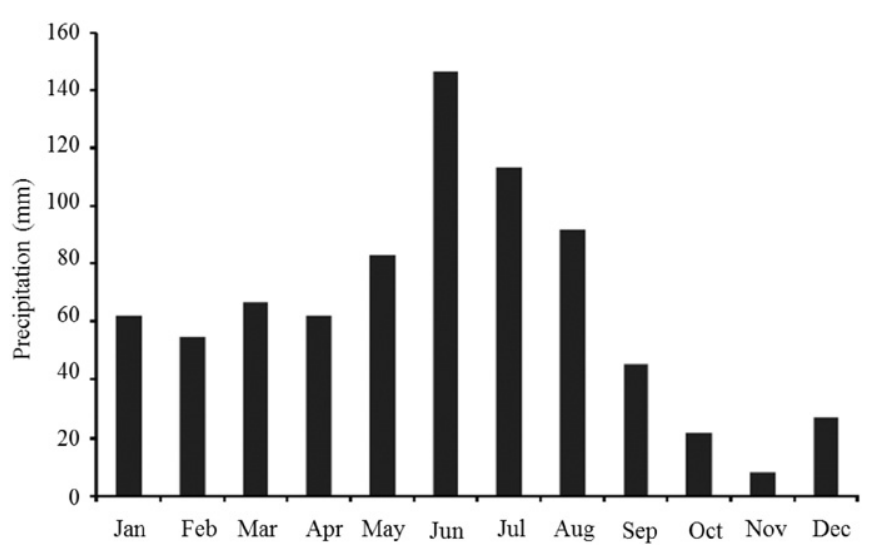

Fig. 2. Mean monthly rainfall (1999-2011) in the municipality of São João, Pernambuco State (APAC, 2015). 


\subsection{Experiment design and collection of soil gas fluxes}

This experiment was set up to assess the impact of LUCC on GHG emissions in the Caatinga biome in two different soil covers: preserved Caatinga forest and pasture. Both covers are located on the same farm. Following convention, the treatment 'Caatinga forest' will be referred to as 'Caatinga'. The fieldwork occurred in 2013 and 2014, with two campaigns per year: one in the dry season (September - April) and the other in the rainy season (May to August).

In each treatment, we measured fluxes of nitrous oxide $\left(\mathrm{N}_{2} \mathrm{O}\right)$, carbon dioxide $\left(\mathrm{CO}_{2}\right)$, and methane $\left(\mathrm{CH}_{4}\right)$ along three $20 \mathrm{~m}$ lines that were established at randomized seed points and followed randomized directions. Each line held six cylindrical PVC chambers consisting of a pipe that served as a base ( $0.24 \mathrm{~m}$ diameter) and a cap that fit snugly on the base (Keller et al., 2005). Chambers were inserted into soil randomly along each row, and each chamber (base + cap) had approximately $10 \mathrm{~L}$. Chambers were inserted $5 \mathrm{~cm}$ into the soil $24 \mathrm{~h}$ before sampling. The collection of gas samples from each line occurred in different periods of the day (L1: 08H0O - 09H00, L2: $12 \mathrm{HOO}$ - 13H0O and L3: $16 \mathrm{HOO}-17 \mathrm{H00}$ ) to capture fluxes in different temperature conditions. Per day, we collected samples in 36 chambers ( 18 in each treatment), totaling 108 chambers per campaign.

Four samples of $60 \mathrm{~mL}$ of the air from the chambers were withdrawn at intervals of 1, 10, 20 and 30 min after closing with $60 \mathrm{~mL}$ syringes and then transferred to previously evacuated glass serum vials sealed with gas impermeable, butyl rubber septum stoppers (Sousa-Neto, 2012). Lab tests showed that gas concentrations were unaffected by storage for up to thirty days (Sousa-Neto, 2012). Samples were analyzed at the Laboratory of the Earth System Science Center (CCST) of the Brazilian Institute for Space Research (INPE) by gas chromatography (SHIMADZU GC-14A Model) for $\mathrm{N}_{2} \mathrm{O}, \mathrm{CO}_{2}$ and $\mathrm{CH}_{4}$ detection, within ten days of collection. The chromatographer was equipped with a packed column, an electron capture detector to analyze $\mathrm{N}_{2} \mathrm{O}$ and a flame ionization detector to quantify $\mathrm{CO}_{2}$ and $\mathrm{CH}_{4}$. Before detection, $\mathrm{CO}_{2}$ was reduced to $\mathrm{CH}_{4}$ using a methanizer (Keller and Reiners, 1994; Varner et al., 2003). Sample gas concentrations were calculated by comparing peak areas of samples to those of commercially prepared standards (White-Martins).

The height of all chambers was measured to estimate the volume of each chamber. Together with gas samples, soil and air temperatures were measured using digital thermometers (Minipa MV-360). In order to assess the influence of temperature over soil gas fluxes, temperatures were divided into four different ranges for comparison against fluxes, as follows: Range $1\left(20-24.9^{\circ} \mathrm{C}\right)$, Range $2\left(25-29.9{ }^{\circ} \mathrm{C}\right)$, Range $3\left(30-34.9^{\circ} \mathrm{C}\right)$, and Range $4\left(35-40{ }^{\circ} \mathrm{C}\right)$.

Soil moisture was also estimated after each collection by soil core samples of about $5 \mathrm{~cm}$ in diameter and $10 \mathrm{~cm}$ of depth. After collection, soil samples were transported to the Laboratory of the Federal Rural University of Pernambuco (Laboratory Centre for Research Support of the Academic Unit of Garanhuns - CENLAG/UFRPE), and a ten grams subsample was oven-dried at $105{ }^{\circ} \mathrm{C}$ for $24 \mathrm{~h}$ to determine water content gravimetrically (Piccolo et al., 1994). Like temperature, soil moisture was divided into ranges for comparison with soil gas fluxes, as follows: R1 (0-19.9\%), R2 (20-39.9\%), R3 (40-59.9\%), R4 (60-79.9\%), and R5 (80-100\%).

Fluxes were calculated from the increase of concentration versus time adjusted for the ratio of chamber volume to area and the air density within the chamber (Keller et al., 2005). Some studies estimated fluxes by linear regression. However, linear regression is not always the best fit for the regression between time and gas concentration in the chamber (Koehler et al., 2009; Kroon et al., 2008). Estimates could be affected if the right regression type is not chosen (Forbrich et al., 2010; Kutzbach et al., 2007). Based on the Akaike criterion, we tested all regression (432 chambers) to find the best fit for flux calculations of each chamber, considering linear, polynomial and exponential models. For all gases, over 95\% of fluxes best fit in linear regression (Table 1).
Table 1

Regressions used (\%) for flux calculation of each chamber, according to Akaike criterion.

\begin{tabular}{llll}
\hline & \multicolumn{2}{l}{ Regression-type (\%) } \\
\cline { 2 - 4 } Gas & Linear & Quadratic & Exponential \\
\hline $\mathrm{N}_{2} \mathrm{O}$ & 99 & 1 & 0 \\
$\mathrm{CO}_{2}$ & 97 & 2 & 1 \\
$\mathrm{CH}_{4}$ & 99 & 1 & 0 \\
\hline
\end{tabular}

\section{Statistical analysis}

All variables were tested for normal distribution and homogeneity of variance before any statistical analysis using Kolmogorov-Smirnov and Levene's tests, respectively. Data were transformed using box-cox transformation whether the above premises were not satisfied. We analyzed gas flux averages and soil temperature and moisture in a 2-way ANOVA design comparing the response variables among treatments, season, and year. Tukey's posthoc analysis was used to clarify any significant difference detected by ANOVA. Linear Pearson correlation analysis and linear regression analysis were used to verify a possible relationship between mean gas fluxes and soil temperature and moisture. All tests were assumed significant at $P<0.05$. Statistical analyses were performed using Statistica v. 12.0 (Statsoft, Tulsa, OK, EUA).

\section{Results}

\subsection{Soil temperature and moisture}

Soil temperature was significantly higher during dry seasons for both years in both Caatinga and Pasture treatments $(P=0.000$; Fig. 3). Mean soil temperatures measured during the dry season in 2013 and 2014 were $31.9 \pm 3.0^{\circ} \mathrm{C}$ and $29.4 \pm 3.0^{\circ} \mathrm{C}$, respectively. During the rainy season, mean soil temperatures were $24.7 \pm 1.4^{\circ} \mathrm{C}$ and $22.8 \pm 1.7^{\circ} \mathrm{C}$ for 2013 and 2014 , respectively. Temperatures were also different between treatments $(P=0.005)$ : pasture soil temperature (mean $27.0 \pm 4.2^{\circ} \mathrm{C}$ ) was two degrees warmer than Caatinga soil temperature (mean $25.8 \pm 40{ }^{\circ} \mathrm{C}$ ). Throughout the day, higher temperatures were measured between $12 \mathrm{H} 00$ and $16 \mathrm{H} 00(P=0.000)$, and values ranged between $20.7{ }^{\circ} \mathrm{C}$ and $37.3^{\circ} \mathrm{C}$. During the morning $(\sim 09 \mathrm{H} 00)$, temperatures were approximately three degrees lower than in the afternoon (Fig. 4).

Soil moisture (gravimetric humidity) was significantly different throughout the campaigns, and values were higher during 2014 for

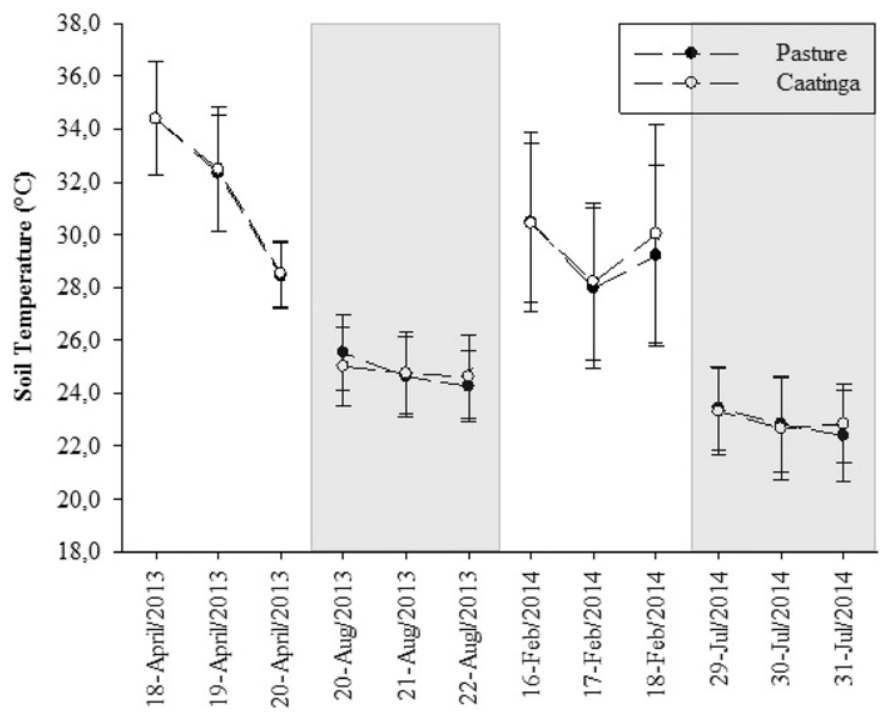

Fig. 3. Soil temperature measured during rainy (shaded regions) and dry season of 2013 and 2014. Solid symbols represent pasture and open symbols represent Caatinga forest. 
both seasons compared to $2013(P=0.000)$. Most values ranged between $3 \%$ and $6 \%$ (Fig. 5). For both years, the soil was wetter in the pasture than in the Caatinga during the rainy season $(P=0.000)$. Soil moisture did not vary significantly at different times of each day of collection.

Soil temperature and soil moisture presented a negative correlation $(r=-0.56 ; P<0.05)$; i. e. temperature decreases as soil moisture increases.

\subsection{Soil-atmosphere gas fluxes}

\subsubsection{Nitrous oxide $-\mathrm{N}_{2} \mathrm{O}$}

Nitrous oxide fluxes ranged from -1.0 to $4.2 \mathrm{mg} \mathrm{m}^{-2} \mathrm{~d}^{-1}$ and -1.22 to $3.4 \mathrm{mg} \mathrm{m}^{-2} \mathrm{~d}^{-1}$, in the pasture (annual average: $0.30 \pm$ $0.03 \mathrm{mg} \mathrm{m}^{-2} \mathrm{~d}^{-1}$ ) and in the Caatinga (annual average: $0.23 \pm$ $0.02 \mathrm{mg} \mathrm{m}^{-2} \mathrm{~d}^{-1}$ ), respectively (Fig. 6). No significant differences were found between data from Caatinga and Pasture. Comparing fluxes between the two years of sampling, $\mathrm{N}_{2} \mathrm{O}$ was significantly higher in 2014 than in $2013(P=0.0000)$ in both treatments. Seasonally, $\mathrm{N}_{2} \mathrm{O}$ emissions were higher in the dry season compared to the rainy season, for both 2013 and $2014(P=0.0000)$.

Nitrous oxide fluxes seemed to be influenced by different temperature ranges $(r=0.36 ; P=0.000 ;$ Fig. 7$)$. In a range of temperatures from $30{ }^{\circ} \mathrm{C}$ to $34.9{ }^{\circ} \mathrm{C}(R 3)$, emissions were significantly higher in the other temperature ranges $(P=0.000)$. Fluxes did not present significant correlation with soil moisture.

\subsubsection{Carbon dioxide - $\mathrm{CO}_{2}$}

No significant differences were found between treatments. Carbon dioxide ranged from -1.1 to $14.1 \mathrm{~g}^{-2} \mathrm{~d}^{-1}$ in the pasture (annual mean: $6.1 \pm 3.6 \mathrm{~g} \mathrm{~m}^{-2} \mathrm{~d}^{-1}$ ), and from -1.2 to $15.8 \mathrm{~g} \mathrm{~m}^{-2} \mathrm{~d}^{-1}$ in the Caatinga (annual mean: $6.1 \pm 3.7 \mathrm{~g} \mathrm{~m}^{-2} \mathrm{~d}^{-1}$ ), (Fig. 8 ). In both treatments, $\mathrm{CO}_{2}$ was significantly higher in 2014 than in $2013(P=$ 0.0000 ). In 2013, rainy season presented higher $\mathrm{CO}_{2}$ emissions compared to dry season $(P=0.0000)$ in both treatments. In 2014 , there were no significant differences in emissions between seasons.



Fig. 5. Soil moisture (as gravimetric humidity) measured during rainy (shaded regions) and dry season of 2013 and 2014. Solid symbols represent pasture, and open symbols represent Caatinga forest.

Carbon dioxide fluxes presented a negative correlation $(r=-0.33$; $P=0.000)$; i.e. emissions tend to decrease with soil temperature elevation. Consequently, $\mathrm{CO}_{2}$ emissions were significantly $(P=0.000)$ higher in Range $1\left(20-24.9^{\circ} \mathrm{C}\right)$ and decreased as temperature increased (Fig. $9 a)$. On the other hand, fluxes presented a significant positive correlation $(r=0.46 ; P=0.000)$ with soil moisture and higher fluxes were measured $(P=0.000)$ in soil moisture ranges between 4 and 5 (Fig. 9b).

\subsubsection{Methane - $\mathrm{CH}_{4}$}

Methane fluxes ranged from 6.6 to $6.8 \mathrm{mg} \mathrm{m}^{-2} \mathrm{~d}^{-1}$ in the pasture (annual mean: $0.4 \pm 0.2 \mathrm{mg} \mathrm{m} \mathrm{m}^{-2} \mathrm{~d}^{-1}$ ), and from -6.0 to $4.8 \mathrm{mg} \mathrm{m}^{-2} \mathrm{~d}^{-1}$ in the Caatinga (annual mean: $0.28 \pm$

\section{Dry Season}

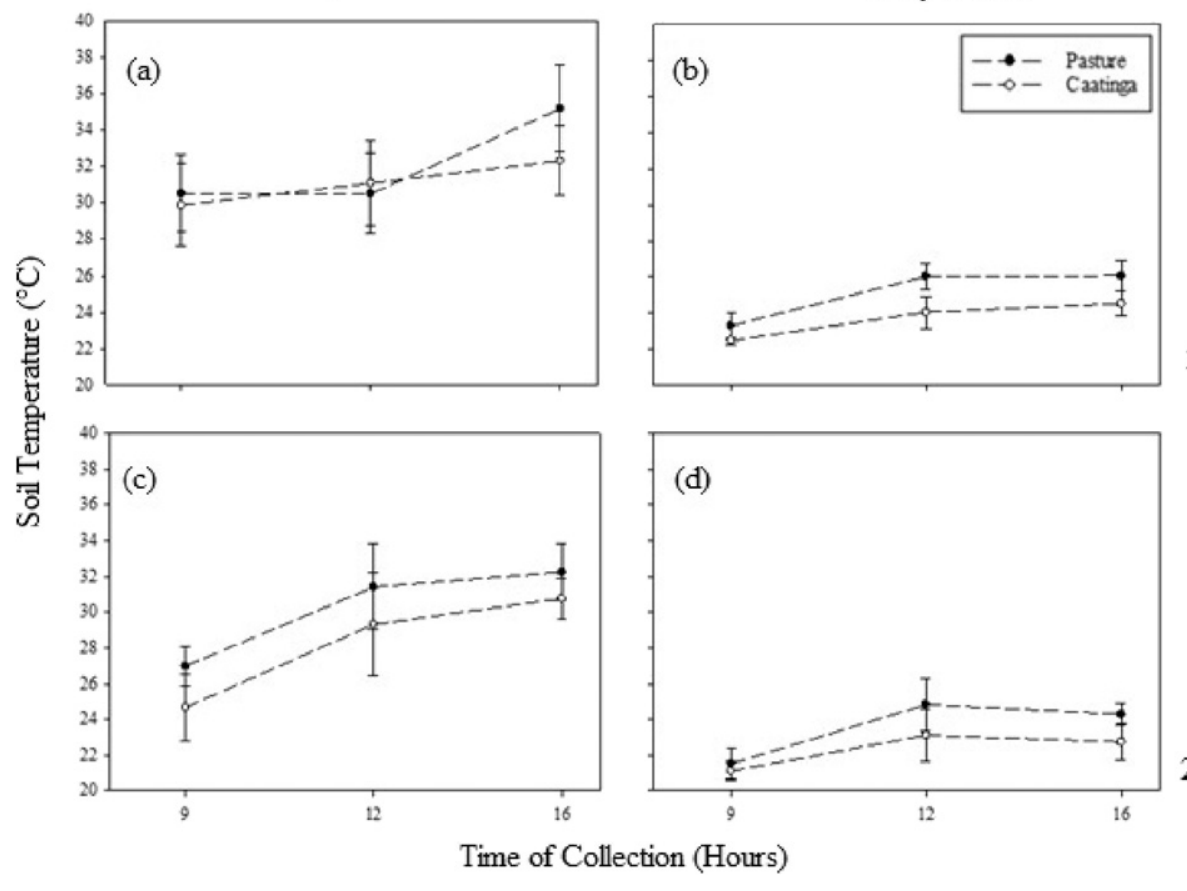

2013


Caatinga (open symbols). 


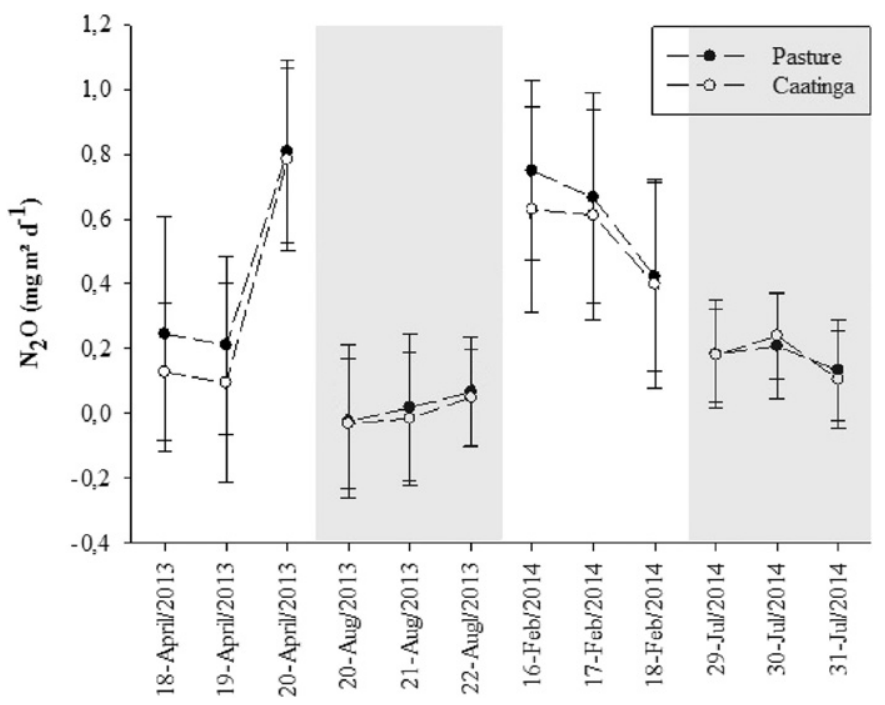

Fig. 6. Soil nitrous oxide fluxes ( $\mathrm{mg} \mathrm{m}^{-2} \mathrm{~d}^{-1}$ ) measured in the pasture and in the Caatinga forest in Pernambuco State in rainy (shaded regions) and dry seasons of 2013 and 2014. Solid symbols correspond to pasture, and open symbols correspond to Caatinga.

$0.1 \mathrm{mg} \mathrm{m}^{-2} \mathrm{~d}^{-1}$ ) (Fig. 10). Methane emissions were significantly higher only in the Caatinga in the rainy season of 2014, compared to the other seasons $(P=0.02)$. Fluxes did not vary significantly among the different times of collection. No correlation of $\mathrm{CH}_{4}$ fluxes and soil temperature or soil moisture was found during collections.

\section{Discussion}

\subsection{Soil- atmosphere gas fluxes in the caatinga biome}

\subsection{1. $\mathrm{N}_{2} \mathrm{O}$ fluxes}

As expected, soil gas fluxes were significantly influenced by soil cover, as well as by different climatic and edaphic conditions. Studies have shown that land cover changes directly affect several ecosystem dynamics such as loss of biodiversity, water and energy balance, and nutrient dynamic such as in nitrogen and carbon (Davidson et al., 1991; Garcia-Montiel et al. n.d.; Muñoz et al., 2010; Ometto et al., 2011). Our results show that gas fluxes were mostly positive, indicating emission of GHG from soil to atmosphere and that emissions vary with season according to the gas species. Soil $\mathrm{N}_{2} \mathrm{O}$ emissions can be highly variable over time, and they are regulated by different factors such as soil



Fig. 7. Nitrous oxide emissions according to different soil temperature ranges: R1 (20$\left.24.9^{\circ} \mathrm{C}\right), \mathrm{R} 2\left(25-29.9{ }^{\circ} \mathrm{C}\right), \mathrm{R} 3\left(30-34.9{ }^{\circ} \mathrm{C}\right)$, and R4 $\left(35-40{ }^{\circ} \mathrm{C}\right)$. water content, temperature, aeration, ammonium, and nitrate concentrations, pH, mineralizable C, among others (Bouwman, 1990; Davidson et al., 2000; Ponce-Mendoza et al., 2010; Tiedje, 1988). Soil moisture is a major driver of $\mathrm{N}_{2} \mathrm{O}$ as it regulates the oxygen available to soil microbes (Butterbach-Bahl et al., 2013; Davidson et al., 2000), even though, in this study, soil moisture did not show any evident effects on $\mathrm{N}_{2} \mathrm{O}$ emissions. Nevertheless, high $\mathrm{N}_{2} \mathrm{O}$ soil emissions were found in samples collected in the dry season, and they were significantly associated with soil temperature in the range of $30-35^{\circ} \mathrm{C}$, which shows the influence of temperature over the nitrogen dynamics. Such influence of temperature over $\mathrm{N}_{2} \mathrm{O}$ emissions has been shown in other studies (Davidson et al., 1991; Garcia-Montiel et al. n.d.; Muñoz et al., 2010; Sousa-Neto, 2012). One hypothesis is based on the fact that denitrification can be extremely sensitive to rising temperatures due to increases in soil respiration induced by temperature that leads to depletion of soil oxygen concentrations and increases in soil anaerobiosis. In a low oxygen environment, the denitrification process is enhanced, and thus $\mathrm{N}_{2} \mathrm{O}$ production may increase. This process shows a tight coupling between the microbial $\mathrm{C}$ and $\mathrm{N}$ cycle, which could explain the high levels of $\mathrm{N}_{2} \mathrm{O}$ emissions observed in this study (Butterbach-Bahl et al., 2013; Schindlbacher et al., 2004). This might also be indicative of increased $\mathrm{N}_{2} \mathrm{O}$ emissions with a positive trend in atmospheric temperature due to climate change. Scenarios for the Brazilian Northeast region indicate a rise in temperature between 0.5 and $4{ }^{\circ} \mathrm{C}$ by 2100 and a reduction of precipitation of 10-20\% (IPCC, 2014; Magrin et al., 2014; Marengo et al., 2009), which raises concerns for future $\mathrm{N}_{2} \mathrm{O}$ emissions.

No differences in $\mathrm{N}_{2} \mathrm{O}$ emissions were found between Caatinga and pasture, and monthly mean flux values seem to be almost overlapping as shown in Fig. 5. Such proximity of mean fluxes suggests that soil of both treatments (regardless of coverage) might be similar regarding $\mathrm{N}$ content, which could explain the similarity in $\mathrm{N}_{2} \mathrm{O}$ fluxes. According to some studies, semiarid soils are considered poor regarding stocks of $\mathrm{N}$ (Cavalcanti et al., 1998; Menezes et al., 2012) and we believe that $\mathrm{N}$ content might be constant throughout the temperature range of both soil cover types.

\subsection{2. $\mathrm{CO}_{2}$ fluxes}

Carbon dioxide fluxes presented high emissions in the rainy season when the soil held the highest water content. As shown previously, $\mathrm{CO}_{2}$ fluxes were significantly related to soil moisture which illustrated how soil conditions are likely to be important and that their effects can be both positive and negative on soil respiration (Davidson et al., 2006). Among several assumptions, variation in soil water content can affect the diffusion of soluble substrates and diffusion of oxygen, which can affect soil microbial respiration (Davidson et al., 2006; Linn and Doran, 1984). Substrate availability was not measured in this study, even though, we believe it might have affected fluxes since substrate accompanies changes in soil moisture (becomes more soluble), which clearly affects soil respiration and enhances $\mathrm{CO}_{2}$ production (Davidson et al., 2006). Some studies have shown pulses of $\mathrm{CO}_{2}$ production following wetting of dry soils, and they attributed such pulses to death of microbial cells during drought and/or release of organic compost in soil solution which works as substrate for living microbes which respond almost instantaneously to this sudden burst of substrate availability (Davidson et al., 2006). Jia et al. (2013) have shown in a semiarid grassland in northern China, positive effects on $\mathrm{CO}_{2}$ emissions with water addition in soil. They demonstrated that the addition of water increased soil $\mathrm{CO}_{2}$ effluxes in two grasslands over two years.

$\mathrm{CO}_{2}$ fluxes were also sensitive to soil temperature, but their correlation was negative; thus, fluxes decreased in elevated temperature ranges. We believe that the negative correlation of gas and temperature are due to increases in soil moisture since our data showed a negative correlation between soil temperature and moisture. The variation in soil water content affects temperature since soil wetting decreases soil warming. Besides, some microbes responsible for soil matter decomposition present high activity in elevated ranges of temperature or tend to 


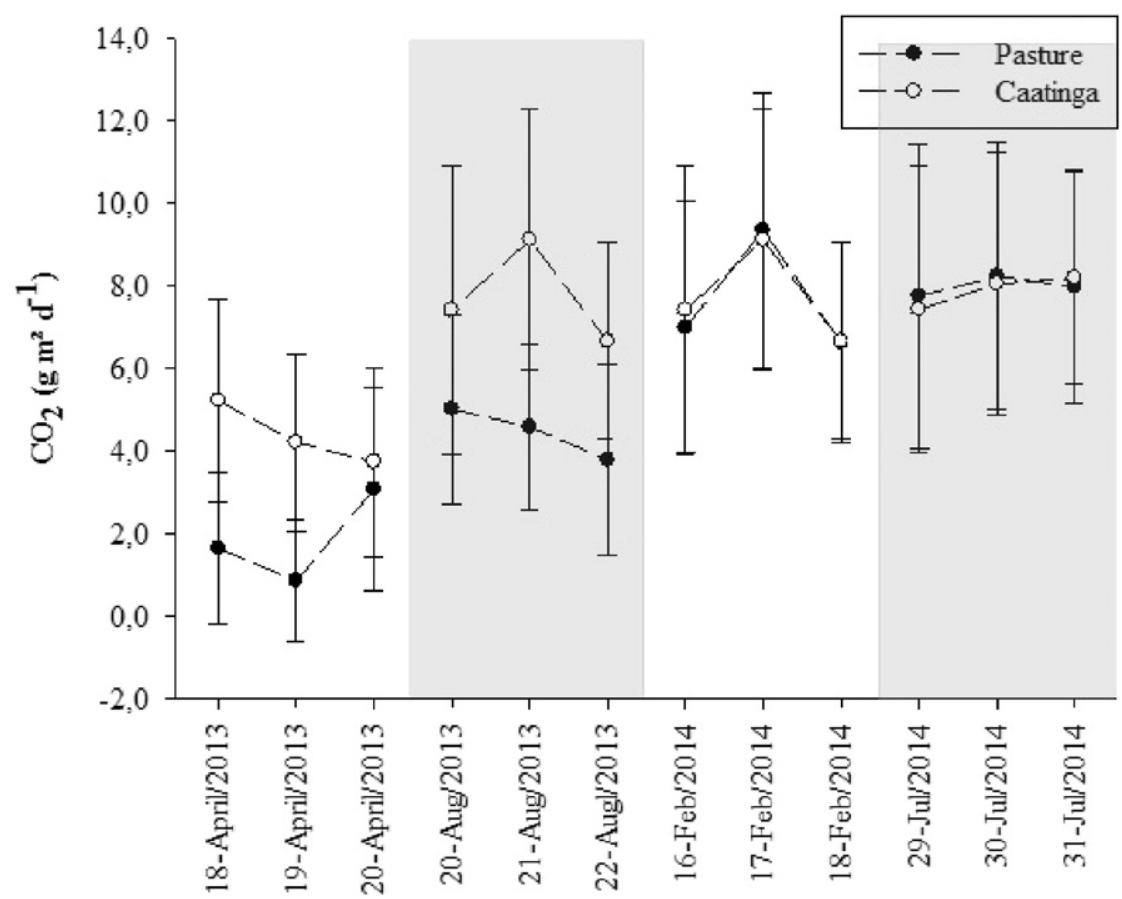

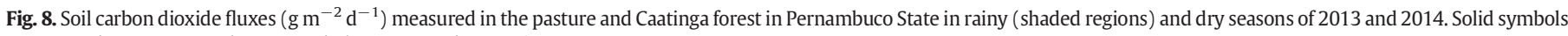
correspond to pasture, and open symbols correspond to Caatinga.

decline in the long-term if submitted to extended warmer periods (Karhu et al., 2014).

Despite a correlation of $\mathrm{CO}_{2}$ flux with soil temperature and moisture, we cannot say with certainty which processes are involved in the gas production. An impediment of this study is that the underlying physiological processes affected by moisture and temperature are not addressed.

\subsection{3. $\mathrm{CH}_{4}$ fluxes}

Due to moisture limitations, many researchers believe that semiarid soils are not significant consumers or producers of trace gases, and these regions are often overlooked in greenhouse gas inventories (Bowden, 1986; McLain and Martens, 2006; Strieg et al., 1992). Furthermore, soil-atmosphere fluxes of $\mathrm{CH}_{4}$ are a complex phenomenon. In our study, no correlation between fluxes and soil moisture or soil temperature was found. Even though methane is a product of organic carbon degradation performed by microorganisms in an anaerobic environment (Megonigal et al., 2004; Megonigal and Guenther, 2008), we believe that $\mathrm{CH}_{4}$ emissions from Caatinga soil during rainy seasons of 2014 are due to soil moisture which promoted an $\mathrm{O}_{2}$-free environment that could have activated methanogen microbes to begin decomposing the organic matter available in the soil leading to $\mathrm{CH}_{4}$ emissions. Likewise, (Verchot et al., 2000) considered that an increase in soil respiration decreases the available $\mathrm{O}_{2}$ and decreases $\mathrm{CH}_{4}$ oxidation coupled with a decrease in the $\mathrm{O}_{2}$ diffusivity caused by an increase in the soil moisture which leads to an increase in the $\mathrm{CH}_{4}$ concentration. Other factors are linked to land use changes since they may affect the methanotrophic/methanogen community composition as observed in forest-to-pasture and forest-to-cropland conversions (Knief and Dunfield, 2005; Singh et al., 1997).

Regardless of the emissions found during the rainy season in the Caatinga, soils acted mostly as sinks of $\mathrm{CH}_{4}$. Many studies have shown that upland tropical forest soils are generally $\mathrm{CH}_{4}$ sinks, mainly in dry seasons when soil moisture is near zero and methanotrophic bacteria consume atmospheric $\mathrm{CH}_{4}$ as a source of C (Carmo et al., 2012; Keller et al., 2005; Megonigal et al., 2004; Megonigal and Guenther, 2008; Sousa-Neto, 2012; Strieg et al., 1992). McLain and Martens (2006) studying $\mathrm{CH}_{4}$ fluxes in riparian vegetation in a semiarid ecosystem found consumption of methane in extremely dry soils. Our study presented both emission and consumption of $\mathrm{CH}_{4}$ according to seasonality and soil cover type, which leads us to believe that land cover changes allied with shifts in precipitation regime may affect fluxes of $\mathrm{CH}_{4}$.

\subsection{Soil GHG emission from caatinga and its role in the Brazilian context}

Scientific information of soil gas fluxes in arid and semiarid ecosystems in northeastern Brazil remain scarce (McHugh et al., 2015; McLain and Martens, 2006). Understanding the factors (whether biotic or abiotic) that affect the control and production of GHG in arid and semiarid soils are of particular importance for understanding the potential mitigation, since dry lands account for $41 \%$ of the surface of the planet and directly influence global C cycling (McHugh et al., 2015). Recent studies (McHugh et al., 2015) have revealed new information about the behavior of arid and semiarid regions about humidity, temperature, influencing the functioning of biogeochemical cycles and $\mathrm{CO}_{2}$ emissions by soils. McLain and Martens (2006) suggest that soils of semiarid regions can act as important GHG sinks such as methane.

Nevertheless, in the Caatinga few studies have been done on its soil biota behavior and factors of production and consumption of GHG. In the national level, the emissions caused by changes in coverage and land use rank in 5th place compared to most altered biomes such as the Amazon and the Cerrado (Table 2).

Based on studies carried out in different biomes of Brazil (Table 3), it was possible to infer the Caatinga contribution to the national output of GHG emissions. It is important to mention that the data used for this comparison refer to this study and do not necessarily represent the behavior of the biome in all regions.

According to MCTI (2013) emission estimates from land use change and forest sector in the Caatinga biome in 2010 was about $6 \mathrm{Gg} \mathrm{CO}_{2} \mathrm{eq}$, mostly related to deforestation and change in land use, representing $2.1 \%$ of the emissions of the sector in Brazil.

In the Caatinga, the factors that influence these emissions are related to replacement of native forests and implementation of agro-pastoral systems. The pasture area in the biome area extends over $293,756.4 \mathrm{~km}^{2}$, representing $35.5 \%$ of the biome and $19.8 \%$ of the pasture area of Brazil (Bustamante et al., 2012). 



Fig. 9. (a) Carbon dioxide emissions according to different temperature ranges: $R 1$ (20$\left.24.9{ }^{\circ} \mathrm{C}\right), \mathrm{R} 2\left(25-29.9{ }^{\circ} \mathrm{C}\right), \mathrm{R} 3\left(30-34.9{ }^{\circ} \mathrm{C}\right)$, and $\mathrm{R} 4\left(35-40{ }^{\circ} \mathrm{C}\right)$; (b) $\mathrm{CO}_{2}$ emissions according to different soil moisture ranges: R1 (0.0-1.99\%), R2 (2.0-3.99\%), R3 (4.0$5.99 \%)$, R4 (6.0-7.99\%), and R5 (8.0-10.0\%).

The drivers of GHG emissions vary by region. Unlike the logging and lumber industry in the Amazon, deforestation in the Caatinga occurs for other purposes such as agriculture, household cooking and energy, use of wood as fuel for the steel industry and to fuel furnaces of dairy industries, in addition to land use for maintaining livestock pasture. In the Caatinga, in some cases, there is no destruction of vegetation, but limited damage caused by animals grazing on the vegetation, causing impact to ground and therefore to vegetation.

As mentioned previously, very few is known about the history of land cover transition in the Brazilian semiarid. The first study that attempted to asses forest cover changes was made by Beuchle et al. (2015) based on the analysis of a systematic sampling of Landsat images. The study showed that from 1990 to 2010, the Caatinga biome has been under continuous net loss of natural vegetation and has lost $15,571 \mathrm{~km}^{2}$, which stands for an annual rate of net forest cover change of $-0.53 \%$. LUC is corroborated by the increase in the annual rate of net natural vegetation loss over two decades from -0.19 (1990-2000) to $-0.44 \%$ (2000 - 2010) (Beuchle et al., 2015). LUC rises other concern than GHG emission because in sensitive regions such as Caatinga this may increase the risks of desertification. Vieira et al. (2015) showed that between 2000 and 2010, northeast Brazil has experienced a fast economic growth and has gone through severe land use and land

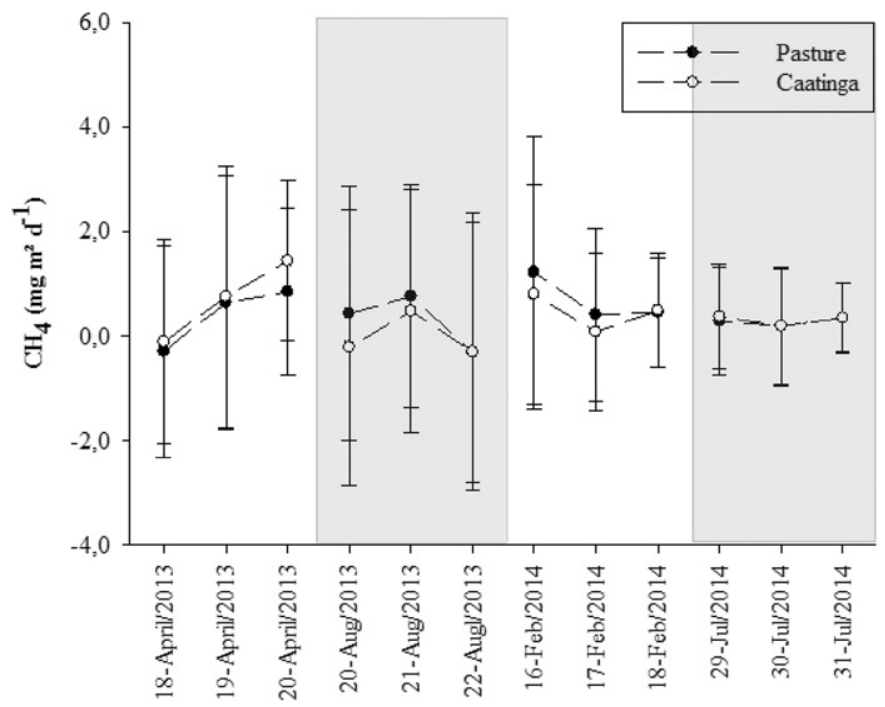

Fig. 10. Soil methane fluxes $\left(\mathrm{mg} \mathrm{m}^{-2} \mathrm{~d}^{-1}\right)$ measured in the pasture and Caatinga forest in Pernambuco State in rainy (shaded regions) and dry seasons of 2013 and 2014. Solid symbols correspond to pasture, and open symbols correspond to Caatinga.

cover changes. Such changes have led to an increase in areas classified as "sensitive" to desertification processes from 35 to 39.6\%, which correspond to an increase of $83,856 \mathrm{~km}^{2}$ (Vieira et al., 2015).

Emissions from Caatinga soils are generally lower than observed in other biomes of Brazil (Table 3). The $\mathrm{CO}_{2}$ contribution was the most significant observed in the experiment, followed by $\mathrm{N}_{2} \mathrm{O}$ and $\mathrm{CH}_{4}$, which are directly connected to the presence of water and temperature, which are strongly influenced by the variability of the biome. However, it is too early to take such a position on Caatinga emissions since there are few studies about soil GHG emissions, which leaves us uncertain as to the real contribution of the biome to the current national GHG emissions.

In an international context, our results corroborates with other studies made in other arid and semiarid systems where LULC changes have caused alteration in soil properties such as soil carbon content, soil moisture and temperature (Jiang et al., 2015; Oyonarte et al., 2007). Soil C content and soil moisture are considered as indicators of soil cover changes (Oyonarte et al., 2007) and, as mentioned previously, they can affect significantly soil gas fluxes, unbalancing soil gas emission/consumption in dry lands.

\section{Conclusions}

Our findings show that changes in land cover are not the major drivers of significant emissions in the Caatinga biome, and they showed the influence of edaphic conditions and climatic factors over soil gas production. Also, they show that, together, soil cover type and climatic condition may positively affect the GHG production leading to significant emission to the atmosphere. Moreover, land use changes impact important soil attributes such as humidity, temperature, and structure, exposing the surface to direct solar radiation, thus altering microbiological dynamics, varying between high and low soil respiration rates and

Table 2

Contribution of each Brazilian Biome to GHG emission for Land Use Change and Forest Sector (MCTI, 2013).

\begin{tabular}{ll}
\hline Amazon forest & $50.3 \%$ \\
Cerrado (Savanna) & $39.1 \%$ \\
Pampa & $5.6 \%$ \\
Caatinga & $2.1 \%$ \\
Pantanal & 0.1 \\
Atlantic Forest & $-1.8 \%$ \\
\hline
\end{tabular}


Table 3

Brazilian biomes and GHG emissions.

\begin{tabular}{|c|c|c|c|c|c|c|}
\hline & \multicolumn{3}{|l|}{ Native vegetation } & \multicolumn{3}{|l|}{ Anthropic use } \\
\hline & $\mathrm{CO}_{2}$ & $\mathrm{~N}_{2} \mathrm{O}$ & $\mathrm{CH}_{4}$ & $\mathrm{CO}_{2}$ & $\mathrm{~N}_{2} \mathrm{O}$ & $\mathrm{CH}_{4}$ \\
\hline & $\overline{\mathrm{Mg} \mathrm{ha}^{-1} \mathrm{ano}^{-1}}$ & $\overline{\mathrm{kg} \cdot \mathrm{ha}^{-1} \mathrm{ano}^{-1}}$ & $\overline{\mathrm{mg} \mathrm{ha}}{ }^{-1} \mathrm{ano}^{-1}$ & $\overline{\mathrm{kg} \cdot \mathrm{ha}^{-1} \mathrm{ano}^{-1}}$ & & \\
\hline${ }^{\mathrm{a} C}$ Cerrado & ${ }^{1} 35.04$ & ${ }^{2} 1.2$ & ${ }^{2}-3.2$ & ${ }^{1} 26.28$ & ${ }^{2} 0.8$ & ${ }^{2} 2.9$ \\
\hline${ }^{\mathrm{b}}$ Amazon Forest & ${ }^{3} 13.58$ & ${ }^{4} 2.5$ & ${ }^{5} 0.0$ & ${ }^{3} 23.72$ & 53.2 & ${ }^{5} 0.0$ \\
\hline${ }^{\mathrm{c}}$ Atlantic Forest & 35.04 & 4.4 & -15.8 & 60.44 & 2.6 & -5.3 \\
\hline${ }^{\mathrm{d}}$ Caatinga & 22.26 & 0.9 & 1.0 & 22.08 & 1.1 & 1.5 \\
\hline
\end{tabular}



thus resulting in higher/low emissions of GHG. The organic matter, availability of nutrients, and microbial activity are minimized in very dry soil conditions, and the occurrence of rainfall events stimulates microbiological activities increasing emissions of $\mathrm{CO}_{2}$ and $\mathrm{N}_{2} \mathrm{O}$. The environmental variables (temperature and soil moisture) are important regulators in GHG; however, the climate and high rainfall variability inherent in the environment, associated with anthropogenic changes in the region hamper determining emissions trends for the biome. Knowledge of the dynamics of greenhouse gases in semiarid regions is of utmost importance for the understanding of global climate change, as arid and semiarid lands cover approximately $41 \%$ of the Earth's surface. Thus, studies that include the understanding of the dynamics of biogeochemical cycles in the region should be applied in various areas of the region.

\section{Acknowledgement}

We thank FAPESP/FACEPE for the financial support given under the project 2009/52468-0; InterAmerican Institute for Global Change Research (IAI) under the project Nnet CRN3005; MCTI/CNPq/ANA N ${ }^{\circ} 23$ / 2015 - Research on Climate Change. We are also grateful to the Riacho do Papagaio farm for letting us install our experiment on their property, and to the Federal Rural University of Pernambuco for laboratory support and fieldwork by students. We thank the laboratory of Gas Chromatography of INPE for the analysis of our samples. We are grateful to the support given by the board of research and technicians MS. Willian José Ferreira, Dr. Maria Cristina Forti, MS. Karinne Reis Deusdará Leal, Eng. Jorge Jofre and Mariana de Almeida Souza.

\section{References}

APAC, 2015. Agência Pernambucana de Águas e Clima 2015. http://www.apac.pe.gov.br. Barbieri, A.F., 2011. Mudanças climáticas, mobilidade populacional e cenários de vulnerabilidade para o Brasil. Rev. Interdiscip. Mob. Hum. 19.

Beuchle, R., Grecchi, R.C., Shimabukuro, Y.E., Seliger, R., Eva, H.D., Sano, E., et al., 2015. Land cover changes in the Brazilian Cerrado and Caatinga biomes from 1990 to 2010 based on a systematic remote sensing sampling approach. Appl. Geogr. 58 $116-127$.

Bortolon, E.S.O., Mielniczuk, J., Tornquist, C.G., Lopes, F., Fernandes, F.F., 2009. Simulação da dinâmica do carbono e nitrogênio em um Argissolo do Rio Grande do Sul usando modelo Century. Rev. Bras. Ciênc. Solo 33, 1635-1646.

Bouwman, A., 1990. Soils and the Greenhouse Effect: The Present Status and Future Trends Concerning the Effect of Soils and their Cover on the Fluxes of Greenhouse Gas. John Wiley \& Sons Inc.

Bowden, W.B., 1986. Gaseous nitrogen Emmissions from undisturbed terrestrial ecosystems: an assessment of their impacts on local and global nitrogen budgets. Biogeochemistry 2, 249-279.

Bustamante, M.M.C., Nobre, C.A., Smeraldi, R., Aguiar, A.P.D., Barioni, L.G., Ferreira, L.G., et al., 2012. Estimating greenhouse gas emissions from cattle raising in Brazil. Clim. Chang. 115, 559-577.

Butterbach-Bahl, K., Baggs, E.M., Dannenmann, M., Kiese, R., Zechmeister-Boltenstern, S., 2013. Nitrous oxide emissions from soils: how well do we understand the processes and their controls? Philos. Trans. R. Soc. Lond. B Biol. Sci. 368.

Carmo, J.B., Sousa-Neto, E.R., Duarte-Neto, P.J., Ometto, J.P.H.B., Martinelli, L.A., 2012. Conversion of the coastal Atlantic forest to pasture: consequences for the nitrogen cycle and soil greenhouse gas emissions. Agric. Ecosyst. Environ. 148, 37-43.

Cavalcanti, F., Messias, A., Silva, M., Moraes, E., Lira, L., 1998. Avaliação Da Fertilidade Dos Solos de Pernambuco: Resultados de 1997. Proceedings of the XII Reunião Brasileira de Manejo e Conservação Do Solo e Da Água, pp. 365-366.
Cerri, C., Feigl, B., Cerri, C.C., Santos, G., Silva, L., Canelas, L., et al., 2008. Dinâmica Da matéria orgânica Do Solo na Amazônia. Santos, GA; Silva, LS; Canellas, LP pp. 325-358.

Chapuis-Lardy, L., Wrage, N., Metay, A., Chotte, J.-L., Bernoux, M., 2007. Soils, a sink for $\mathrm{N}_{2} \mathrm{O}$ ? A review. Glob. Chang. Biol. 13, 1-17.

Davidson, E.A., Vitousek, P.M., Matson, P.A., Riley, R., García-Méndez, G., Maass, J.M., 1991. Soil emissions of nitric oxide in a seasonally dry tropical forest of México. J. Geophys. Res. Atmos. 96, 15439-15445.

Davidson, E.A., Keller, M., Erickson, H.E., Verchot, L.V., Veldkamp, E., 2000. Testing a conceptual model of soil emissions of nitrous and nitric oxides: using two functions based on soil nitrogen availability and soil water content, the hole-in-the-pipe model characterizes a large fraction of the observed variation of nitric oxide and nitrous oxide emissions from soils. Bioscience 50, 667-680.

Davidson, E.A., Janssens, I.A., Luo, Y., 2006. On the variability of respiration in terrestrial ecosystems: moving beyond Q10. Glob. Chang. Biol. 12, 154-164.

de Freitas, R.A.C., Sizenando Filho, F.A., Maracajá, P.B., Diniz Filho, E.T., de Lira, J.F.B., 2007 Estudo florístico e fitosociológico Do Extrato Arbustivo-Arboreo de Dois Ambientes Em Messias Targino Divisa RN/PB. Revista Verde de Agroecologia e Desenvolvimento Sustentável p. 2

Fleischer, E., Khashimov, I., Hölzel, N., Klemm, O., 2016. Carbon exchange fluxes over peatlands in Western Siberia: possible feedback between land-use change and climate change. Sci. Total Environ. 545-546, 424-433.

Forbrich, I., Kutzbach, L., Hormann, A., Wilmking, M., 2010. A comparison of linear and exponential regression for estimating diffusive $\mathrm{CH}_{4}$ fluxes by closed-chambers in peatlands. Soil Biol. Biochem. 42, 507-515.

Garcia-Montiel, D.C., Steudler, P.A., Piccolo, M., Neill, C., Melillo, J., Cerri, C.C., 2003. Nitrogen oxide emissions following wetting of dry soils in forest and pastures in Rondônia Brazil. Biogeochemistry 64, 319-336.

Garcia-Montiel, D.C., Steudler, P.A., Piccolo, M., Neill, C., Melillo, J., Cerri, C.C., 2016. Nitrogen oxide emissions following wetting of dry soils in forest and pastures in Rondônia, Brazil. Biogeochemistry 64, 319-336.

Gariglio, M.A., Sampaio, E.V.S.B., Cestaro, L.A., Kageyama, P.Y., 2010. Uso sustentável conservação Dos Recursos Florestais Da Caatinga. Serviço Florestal Brasileiro-SFB.

Giulietti, A.M., Bocage Neta, A., Castro, A., Gamarra-Rojas, C., Sampaio, E., Virgínio, J., et al., 2004. Diagnóstico Da vegetação Nativa Do Bioma Caatinga. Biodiversidade Da Caatinga: áreas e ações prioritárias para a conservação, pp. 48-90.

Henry, B.K., Danaher, T., McKeon, G.M., Burrows, W.H., 2002. A review of the potential role of greenhouse gas abatement in native vegetation management in Queensland's rangelands. Rangel. J. 24, 112-132.

Hristov, A.N., Oh, J., Lee, C., Meinen, R., Montes, F., Ott, T., et al., 2013. Mitigation of Greenhouse Gas Emissions in Livestock Production - A Review of Technical Options for Non- $\mathrm{CO}_{2}$ Emissions. 177. FAO, Rome, p. 231.

IBGE, 2004. Instituto Brasileiro de Geografia e Estatística - Sistema IBGE de Recuperação Automática. 2015.

IPCC, Field, C., 2014. Intergovernmental Panel on Climate Change - Climate Change 2014 Impact, Adaptation, and Vulnerability. Contribution of Working Group II to the Fifthe Assessment Report of the Intergovernmental Panel on Climate Change. Cambridge University Press, Cambridge/New York.

Jia, X., Shao, M., Wei, X., 2013. Soil $\mathrm{CO}_{2}$ efflux in response to the addition of water and fertilizer in temperate semiarid grassland in northern China. Plant Soil 373, 125-141.

Jiang, P., Cheng, L., Li, M., Zhao, R., Duan, Y., 2015. Impacts of LUCC on soil properties in the riparian zones of desert oasis with remote sensing data: a case study of the middle Heihe River basin, China. Sci. Total Environ. 506-507, 259-271.

Karhu, K., Auffret, M.D., Dungait, J.A., Hopkins, D.W., Prosser, J.I., Singh, B.K., et al., 2014 Temperature sensitivity of soil respiration rates enhanced by microbial community response. Nature $513,81-84$.

Katharina, H.E.M., Uwe, F., Claus, F.S., Jaqueline Dalla, R., Beata, E.M., Hermann, F.J., 2016 Direct nitrous oxide (N 2 O) fluxes from soils under different land use in Brazil-a critical review. Environ. Res. Lett. 11, 023001.

Keller, M., Reiners, W.A., 1994. Soil-atmosphere exchange of nitrous oxide, nitric oxide, and methane under secondary succession of pasture to forest in the Atlantic lowlands of Costa Rica. Glob. Biogeochem. Cycles 8, 399-409.

Keller, M., Varner, R., Dias, J.D., Silva, H., Crill, P., de Oliveira Jr, R.C., et al., 2005. Soil-atmosphere exchange of nitrous oxide, nitric oxide, methane, and carbon dioxide in logged and undisturbed forest in the Tapajos National Forest, Brazil. Earth Interact. 9, 1-28.

Kirschbaum, M.U.F., 2003. To sink or burn? A discussion of the potential contributions of forests to greenhouse gas balances through storing carbon or providing biofuels. Biomass Bioenergy 24, 297-310.

Knief, C., Dunfield, P.F., 2005. Response and adaptation of different methanotrophic bacteria to low methane mixing ratios. Environ. Microbiol. 7, 1307-1317. 
Koehler, B., Corre, M.D., Veldkamp, E., Wullaert, H., Wright, S.J., 2009. Immediate an long-term nitrogen oxide emissions from tropical forest soils exposed to elevated nitrogen input. Glob. Chang. Biol. 15, 2049-2066.

Kroon, P.S., Hensen, A., Bulk, W.C.M., Jongejan, P.A.C., Vermeulen, A.T., 2008. The importance of reducing the systematic error due to non-linearity in $\mathrm{N}_{2} \mathrm{O}$ flux measurements by static chambers. Nutr. Cycl. Agroecosyst. 82, 175-186.

Kutzbach, L., Schneider, J., Sachs, T., Giebels, M., Nykänen, H., Shurpali, N.J., et al., 2007. CO flux determination by closed-chamber methods can be seriously biased by inappropriate application of linear regression. Biogeosciences 4, 1005-1025.

Leal, I.R., Jd, S., Tabarelli, M., Lacher Jr., T.E., 2005. Mudando o curso da conservação da biodiversidade na Caatinga do Nordeste do Brasil. Megadiversidade 1, 139-146.

Linn, D., Doran, J., 1984. Effect of water-filled pore space on carbon dioxide and nitrous oxide production in tilled and nontilled soils. Soil Sci. Soc. Am. J. 48, 1267-1272.

Magrin, G.O., Marengo, J.A., Boulanger, J.-P., Buckeridge, M.S., Castellanos, E., Poveda, G., et al., 2014. Central and South America. In: Barros, V. (Ed.), Climate Change 2014: Impacts, Adaptation, and Vulnerability. Part B: Regional AspectsContribution of Working Group II to the Fifth Assessment Report of the Intergovernmental Panel on Climate Change. Cambridge University Press, Cambridge/New York

Marengo, J.A., Jones, R., Alves, L., Valverde, M., 2009. Future change of temperature and precipitation extremes in South America as derived from the PRECIS regional climate modeling system. Int. J. Climatol. 29, 2241-2255.

Matson, P., Vitousek, P., 1990. Ecosystem approach to a global nitrous oxide budget. Bioscience 40, 667-672.

McHugh, T.A., Morrissey, E.M., Reed, S.C., Hungate, B.A., Schwartz, E., 2015. Water from air: an overlooked source of moisture in arid and semiarid regions. Sci. Rep. 5.

McLain, J.E., Martens, D.A., 2006. Moisture controls on trace gas fluxes in semiarid riparian soils. Soil Sci. Soc. Am. J. 70, 367-377.

MCTI, 2013. Ministério Da Ciência Tecnologia e Inovação. Estimativas Anuais de Emissões de Gases de Efeito Estufa no Brasil. Ministério Da Ciência, Tecnologia E Inovação, p. 76

Megonigal, J.P., Guenther, A.B., 2008. Methane emissions from upland forest soils and vegetation. Tree Physiol. 28, 491-498.

Megonigal, J., Mines, M., Visscher, P., 2004. Anaerobic Metabolism: Linkages to Trace Gases and Aerobic Processes. In: Schlesinger, W.H. (Ed.), Biogeochemistry, pp. 317-324.

Menezes, R., Sampaio, E., Giongo, V., Pérez-Marin, A., 2012. Biogeochemical cycling in terrestrial ecosystems of the caatinga biome. Braz. J. Biol. 72, 643-653.

MMA, 1998d. In: Ministério do Meio Ambiente dos Recursos Hídricos e da Amazônia Legal (Ed.), Ministério Do Meio Ambiente - Convenção Das Nações Unidas de Combate à desertificação Nos Países Afetados Por Seca Grave e/Ou Desertificação Particularmente na África. Ministério do Meio Ambiente, Brasília, DF, pp. 7-11.

Muñoz, C., Paulino, L., Monreal, C., Zagal, E., 2010. Greenhouse gas $\left(\mathrm{CO}_{2}\right.$ and $\left.\mathrm{N}_{2} \mathrm{O}\right)$ emissions from soils: a review. Chil. J. Agric. Res. 70, 485-497.

Oliveira, S.D., da Silva, V.P.R., dos Santos, C.A.C., Silva, M.T., de Sousa, E.P., 2012. Os Impactos das Alterações Climáticas na Cana-de-Açúcar Cultivada em Sistema de Sequeiro na Região Nordeste do Brasil (the impacts of the climate changes on suga cane cultivated in Rainfed Systems in Northeastern of Brazil). Rev. Bras. Geogr. Fís. $5,170-184$

Ometto, J.P., Aguiar, A.P.D., Martinelli, L.A., 2011. Amazon deforestation in Brazil: effects drivers and challenges. Carbon Manage. 2, 575-585.

Oyonarte, C., Mingorance, M.D., Durante, P., Piñero, G., Barahona, E., 2007. Indicators of change in the organic matter in arid soils. Sci. Total Environ. 378, 133-137.

Pereira, I., 2000. Levantamento florístico Do Estrato Arbustivo-Arboreo e análise Da Estrutura fitossociológica de Ecossistema de Caatinga Sob Diferentes níveis de Antropismo. Universidade Federal da Paraíba, p. 70 (MSc).

Pereira Filho, J., Bakke, O., 2010. Produção de Forragem de espécies herbáceas Da Caatinga. Uso sustentável e conservação Dos Recursos Florestais Da Caatinga. Serviço Florestal Brasileiro, Brasília, pp. 145-159.

Piccolo, M.C., Neill, C., Cerri, C.C., 1994. Net nitrogen mineralization and net nitrification along a tropical forest-to-pasture chronosequence. Plant Soil 162, 61-70.

Pinto, A.S., Bustamante, M.M.C., Kisselle, K., Burke, R., Zepp, R., Viana, L.T., et al., 2002. Soil emissions of $\mathrm{N}_{2} \mathrm{O}, \mathrm{NO}$, and $\mathrm{CO}_{2}$ in Brazilian savannas: effects of vegetation type, seasonality, and prescribed fires. J. Geophys. Res. Atmos. 107 (LBA 57-1-LBA 57-9).

Ponce-Mendoza, A., Ceballos-Ramírez, J.M., Gutierrez-Micelli, F., Dendooven, L., 2010. Emission of nitrous oxide and carbon dioxide from semi-arid tropical soils in Chiapas México. Rev. Bras. Ciênc. Solo 34, 1617-1628.
Redo, D., Aide, T.M., Clark, M.L., 2013. Vegetation change in Brazil's dryland ecoregions and the relationship to crop production and environmental factors: Cerrado, Caatinga, and Mato Grosso, 2001-2009. J. Land Use Sci. 8, 123-153.

Salimon, C., Davidson, E., Victoria, R., Melo, A., 2004. $\mathrm{CO}_{2}$ flux from soil in pastures and forests in southwestern Amazonia. Glob. Chang. Biol. 10, 833-843.

Sampaio, E., 2003. Caracterização Da Caatinga e Fatores Ambientais Que Afetam a Ecologia Das Plantas Lenhosas. In: Sales, V. (Ed.), Ecossistemas Brasileiros: Manejo e Conservação. Expressão Gráfica e Editora, Fortaleza, pp. 129-142 (Expressão Gráfica e Editora, Fortaleza).

Sampaio, E.V.S.B., Costa, T.L., 2012. Estoques e Fluxos de carbono no semi-Árido nordestino: Estimativas Preliminares (stocks and fluxes of carbon in semiarid Northeast Brazil: preliminary estimates). Rev. Bras. Geogr. Fís. 4, 1275-1291.

Sampaio, E., Freitas, A., 2008. Produção de Biomessa na vegetação Nativa Do Semi-árido Nordestino. In: Menezes, R., Sampaio, E., Salcedo, I. (Eds.), Fertilidade Do Solo e Produção de Biomessa no Semi-árido. Editora Universitária/UFPE, Recife, pp. 11-26.

Santos, J.C., Leal, I.R., Almeida-Cortez, J.S., Fernandes, G.W., Tabarelli, M., 2011a. Caatinga: the scientific negligence experienced by a dry tropical forest. Trop. Conserv. Sci. 4.

Santos, R.S., Costa, L.C., Sediyama, G.C., Leal, B.G., Oliveira, R.A., Justino, F.B., 2011b. Avaliação da relação seca/produtividade agrícola em cenário de mudanças climáticas. Rev. Bras. Meteorol. 26, 313-321

Santos, J.C.B., Souza Júnior, V.S., Corrêa, M.M., Ribeiro, M.R., Almeida, M.C., Borges, L.E.P., 2012. Caracterização de neossolos regolíticos da região semiárida do Estado de Pernambuco. Rev. Bras. Ciênc Solo 36, 683-696.

Schindlbacher, A., Zechmeister-Boltenstern, S., Butterbach-Bahl, K., 2004. Effects of soil moisture and temperature on $\mathrm{NO}, \mathrm{NO}_{2}$, and $\mathrm{N}_{2} \mathrm{O}$ emissions from European forest soils. J. Geophys. Res. Atmos. 109, 12

Singh, J., Singh, S., Raghubanshi, A., Singh, S., Kashyap, A., Reddy, V., 1997. Effect of soil nitrogen, carbon and moisture on methane uptake by dry tropical forest soils. Plant Soil 196, 115-121.

Siqueira Neto, M., Piccolo, M.C., Costa Junior, C., Cerri, C.C., Bernoux, M., 2011. Emissão de gases do efeito estufa em diferentes usos da terra no bioma Cerrado. Rev. Bras. Ciênc Solo 35, 63-76.

Smith, P., Bustamante, M., Ahammad, H., Clark, H., Dong, H., Elsiddig, E.A., et al., 2014. Agriculture, Forestry and Other Land Use (AFOLU). Climate Change 2014: Mitigation of Climate Change. Contribution of Working Group III to the Fifth Assessment Report of the Intergovernmental Panel on Climate Change. Cambridge University Press.

Sousa, F.P., Ferreira, T.O., Mendonça, E.S., Romero, R.E., Oliveira, J.G.B., 2012. Carbon and nitrogen in degraded Brazilian semi-arid soils undergoing desertification. Agric. Ecosyst. Environ. 148, 11-21.

Sousa-Neto, E.R., 2012. Fluxos de óxido Nitroso (N2O), Metano (CH4) e dióxido de Carbono (CO2) a Partir de Um Solo Cultivado Com Cana-de-açúcar Sob Diversos Tratos Culturais. Centro de Energia Nuclear na Agricultura CENAUniversidade de São Paulo, Piracicaba, SP PhD.

Strieg, R., McConnaughey, T., Thorstenson, D., Weeks, E., Woodward, J., 1992. Consumption of atmospheric methane by desert soils. Nature 357, 145-147.

Tiedje, J.M., 1988. Ecology of denitrification and dissimilatory nitrate reduction to ammonium. Biol. Anaerobic microorganisms 717, 179-244.

United States Department of Agriculture - USDA, 2008. In: USDA (Ed.), Agriculture and Forestry Greenhouse Gas Inventory: 1990-2005. USDA, p. 161.

Varner, R.K., Keller, M., Robertson, J.R., Dias, J.D., Silva, H., Crill, P.M., et al., 2003. Experimentally induced root mortality increased nitrous oxide emission from tropical forest soils. Geophys. Res. Lett. 30 n/a-n/a.

Verchot, L.V., Davidson, E.A., Cattânio, J.H., Ackerman, I.L., 2000. Land-use change and biogeochemical controls of methane fluxes in soils of eastern Amazonia. Ecosystems 3, 41-56.

Vieira, R.M.S.P., Tomasella, J., Alvalá, R.C.S., Sestini, M.F., Affonso, A.G., Rodriguez, D.A., et al., 2015. Identifying areas susceptible to desertification in the Brazilian northeast. Solid Earth 6, 347-360.

Watanabe, M.D.B., Ortega, E., 2011. Ecosystem services and biogeochemical cycles on a global scale: valuation of water, carbon and nitrogen processes. Environ. Sci. Pol. 14, 594-604.

Zhao, H.-L., He, Y.-H., Zhou, R.-L., Su, Y.-Z., Li, Y.-Q., Drake, S., 2009. Effects of desertification on soil organic $\mathrm{C}$ and $\mathrm{N}$ content in sandy farmland and grassland of Inner Mongolia. Catena 77, 187-191. 